\title{
Profile of Promoters and Hindering Teachers Creativity: Own or Shared?
}

\author{
Nazira Píriz Giménez \\ Department of Biological Sciences, Education Training Council, Montevideo, Uruguay \\ Email: nazirapiriz@gmail.com
}

Received 6 June 2016; accepted 9 July 2016; published 12 July 2016

Copyright (@ 2016 by author and Scientific Research Publishing Inc.

This work is licensed under the Creative Commons Attribution International License (CC BY).

http://creativecommons.org/licenses/by/4.0/

(c) (i) Open Access

\begin{abstract}
Creativity is now at days a valued quality in all its areas and most particulary in Education. However, there is still widespread ignorance of Creativity in the Formal Education's field and a lack of scientific research about Creativity and Education, particularly in teacher training. In this article, we will present a categorization of teachers in either promoters or hindering of Creativity, based on interview's data. The study was narrowed to the training of teachers in Biologic Sciences of the two Institutions with more students of the country. From an interpretive paradigm and with a qualitative design, semi-structured interviews to students and teachers were made and analyzed by "content". Results show that teachers that highly promote creativity tend to have a close relationship with the student, as well as affectionate, and they are also characterized by recognizing and accepting their own mistakes and limitations. On the other hand, creativity's highly hindering techers tend to be structured, distant, and believe to be all-wise. Additionally, creativity's promoting activities are only remarked by students with a close relationship with the professor. At the same time, an affectionate treatment from the student could lead to creativity's promoting activities by teachers who would normally fit in the hindering type. Considering the previous observation, we propose that affection between students and teachers consists of an essential component of a creative classroom's atmosphere, continuing and amplifying the systematic model of Csikszentmihalyi. Analogously to the conception that a creative product doesn't emerge from an isolated person, it seems appropriate to affirm that a creativity's promoting or hindering profile of a theacher also depends on the interaction with his environment.
\end{abstract}

\section{Keywords}

Creativity, Creative School, Promoting Creativity, Impeding Creativity

\section{Introduction}

The actual world's dynamism and its changes and uncertainties also reach the classrooms. Therefore, more 
creativity to face new chalenges is demanded to teachers. Babicka (2010) expresses: "The modern's world growing complexity demands creativity and originality by individuals and shifts creativity's topics to another dimension. Creativity turns progressively into a teaching/Education category"... "Teachers are forced to be creative people, full of initiative and open minded to engage themselves in complementary challenges”. Above the same line, Ken Robinson, asesor in Education for the United Kingdom, believes creativity is the crucial ability in the XXI century for the resolution of contemporary problems. Meanwhile, in year 2006, the UNESCO's general director of that time, Koïchiro Matsuura said that "creativity is our hope" (Newton \& Newton, 2014). Tenti Fanfani (2013) states the absolute consensus in South America regarding to an Education destined to the development of creativity and of Critical thinking, and expresses the need to implement specific actions to avoid these ideas to only stay on the speech.

In spite of this growing appreciation of Creativity in Education and the abundance of bibliography related to it, some difficulties persist: In the Education's field, the term "creativity" is still used a lot of times whithout making refference to its scientific concept. We considered that as colloquial (Marquis \& Henderson, 2015; Bilhalva \& Blanché, 2015; Tan, 2014; Craft et al., 2014; Henriksen, D., 2014; Meacham, E., 2014; Lewisa \& Elaver, 2014; Adorjan, 2014; Newton \& Newton, 2014; Rebollo \& Soubirón, 2014); it did not exist, prior to this report, elements that evaluate the promotion or obstruction of creativity by teachers, applicable for its generalized use. Soriano de Alencar (2007) proposed in Brazil a tool with these objectives, not available in its complete form on the web.

For the purposes of reversing this situation, it is relevant as a theorical framework a brief summary of the historical evolution and the actual state of the creativity concepts and creative schools.

\section{Contributions of Psychology of Creativity}

The concept of "creativity", as well as the focus on its study, has dramatically changed in the past 100 years. Initially asociated with genius, the centre of attention of creativity has gone from being the creative person, to being the creative idea. At the same time, elements like the environment of creative people and the interactions between both, started to gain interest. Creativity as a quality able to be developed was a proposal firstly made by Joy Guilford, who also associates it to divergent thinking (Romo Santos, 1987). Since then, the sociocultural influence as well as the environmental or ecological one, took hierarchy (Huidobro Salas, 2004). Amabile (1998), proposes as necessary environmental conditions for creativity stimulation: to offer challenges, to give freedom and support, provide resources, form working groups and to supervise their work.

The ecological point of view, represented by Howard Gardner and Mihaly Csikszentmihalyi, hierarchizes the cultural aspects. Csikszentmihalyi proposes a holistic and sistematic model of creativity. He expresses that “...ideas and products that deserve the creative qualifier arrise from the synergy of many sources, and not only from an isolated mind... creativity is the result of the interaction of a system composed by three elements: a culture that contains symbolic rules, a person who brings novelty to the symbolic field and an experts' scope that know and allow the innovation” (Csikszentmihalyi, 1999). “Creativity is not produced insight people's heads, but in the interaction between one person's thoughts and one sociocultural context (Pascale, 2005).

Creative people

Joy Guilford proposed that "creative individuals are characterized by a combination of personality traits such as: sensitivity to problems, ideational fluency, flexibility for adaptation, originality, synthesis capacity, analysis capability, reorganization and redefinition competence, complex data assimilation, and by being capable of evaluate ideas" (Guilford, 1975).

A meta-analysis realized by Feist (1998) shows the association between creativity, autonomy and disbelief. Jiménez Fernández (2000) shares the idea that creative people act with independence of thought and reject conventional criteria or imposed arguments, having agreed that talking about creativity implies talking about questioning.

Csikszenmihalyi proposes that the main characteristic of the creative personality is the preference for complexity. Feeling the presence of a challenge fosters creative solutions.

Huidobro Salas (2004), in his analysis of 24 authors about Creativity, reports the following creative people's personality characteristics, categorized as follows:

"1. Intelectuals: which principal characteristic is the balance between the opening and closing, the reason and the imagination, the fluidity and the concentration. 
2. Not intelectuals of personality: among which stand out individualism, originality and anti-convencionalism.

3. Not intelectuals, motivational: principally the intrinsic motivation (or because of the task) and the exploratory and esthetic interest, contributing this constellation or group of characteristics to enable a person reach his optimum usage of metacognition."

Creative Schools contributions

In search of creativity promotion, the conception of "creative schools" appears. These are characterized by: promoting active learning, focused on the student and not on the content, by priorizing comprehension and not memorization of information among other properties (Ferrari et al., 2009). In this way, the teaching exercise for a creative school implies a large amplitude and diversity of actions that go from promoting (and not inhibit) in its students, qualities proper of creative people (such as selfconfidence and the habit of questioning), to specific didactic actions like problems formulations with divergent solutions, among many others.

According to Saturnino de la Torre (2009), creative teaching is characterized by being active, motivating and dynamic. He also expresses that "the creative teacher possesses certain characteristics... possesses a flexible disposition towards people, decisions and events; he knows and applies/uses various techniques applied to ideation and creativity of his students, not being satisfied with the ones that repeat what they have studied or heard... Among these abilities we can refer to actions like: induce pupils to be sensitized by problems; promote learning by discovery; create an environment where students can feel secure and communication between each others can flow; incite learning and self-discipline; defer critical judgment when ideas are being exposed, stimulate the divergent thoughts, ask and encourage the asking of divergent questions, apply creative techniques..."

At the same time, Elisondo et al. (2009: p. 7) proposes the following: "Liberty, self-regulation, meaningfulness, autonomy and diversity are characteristics of the learning activities that relate to creativity and they increase the chances that the students deploy creative potential in educational context."

Amabile (1983), expresses that in educational environments it is essencial to create an atmosphere in which students and teachers are open to new ideas; flexible and able to adapt to changes. Fear to failure and risks aversion must be decreased as well.

Pérez Alonso-Geta (2009) mentions inhibiting factors of creativity, among these: -teaching with convergent results, unique, that doesn't give place to other ways of acting or of perceiving things. -achievement motivation (extrinsic; -the persuit of the identification with the group and unification, that keeps people from highlighting the actions and things that are different; -not making room for questions; different type of pressures. The author emphasizes that in creative education "it is neccesary the development of self-confidence to allow students to take risks and loose fear to fail, and to help them overcome frustration and obstacles.

Taking into account these records, it is necessary to create a tool that allows us to value promotion or obstruction of creativity by teachers. It should be based on a teorical framework of the Creativity's psychology and the Creative Schools, and also be presented in this article. The application of this codes system enabled us to characterize teachers in that sense and brought unexpected results in the areas of hierarchy between teachers and students, and in the affection's role.

Work contextualization:

This article presents part of the results of a doctoral thesis in Education destined to respond if Creativity is promoted or hampered in teacher training institutions. In this context, it was considered important the idea of reducing the student population to the ones that have the complete backing of the educational system. This determined students and teachers' selection criterias that are mentioned later in the report, although it is not specifically the objective of this investigation.

\section{Objective}

The aim of this research consists of charachterizing teachers as promoters or hindering of creativity.

\section{Methodology}

From an interpretive paradigm and a qualitative design, we wanted to identify to which of the two categories each teacher belonged, starting from semiestructured interviews to teachers and students of the professorship of biologic sciences of the two institutions with more students in Uruguay: the "Instituto de Profesores Artigas" and "Profesorado Semipresencial”, both depend on the "Consejo de Formación en Educación (CFE) (Council of teaching in Education). 
The interviews were designed taking into account the theoretical frameworkof of the Creative Schools and the Psychology of Creativity. In this manner, every promoter or obstructive activity of an active learning focused on the student was explored. Activities and objectives that aim to comprehend and not memorize and that also stimulates characteristics of the creative person such as self-confidence; critical and divergent thinking. It was essencial to use questionnaires that made the interviewee feel free to expand their ideas (e.g: through examples and clarifications) and give open answers, starting from questions that were as less restricted as possible. These elaborated questionnaires were "flexible based" with broad questions and it also gave the possibility to the interviewer to get a closer contact with the inquired, who felt comfortable and free to answer in a spontaneous way.

The presented results were taken from two groups of people: Teachers from the "Instituto de Profesores Artigas" and from "Profesorado Semipresencial”, in the specialty of Biological Sciences, who teach specific subjects ${ }^{1}$ that can be exonerated ${ }^{2}$, with whom at least one student has passed in the 2011 school year; Professorship students on the specialty of Biological Sciences of the same institutions, with at least one of the subjet passed in 2011 with one of the interviewed professors.

\section{Applied Techniques}

It was decided to perform an analysis of qualitative content for the interviews and of a "global” type, with the inductive categories construction (Andréu Abela, 2002).

Given the chosen investigation design, it was not an interest to obtain a representative sample of the population in order to generalize results. However, from the total number of teachers with the criteria defined, more than $80 \%$ were included in the study. Regarding the students, about a $50 \%$ of the ones that met the inclusion requirements were interviewed. According to a qualitative investigation, the sampling ended when the information started to be reiterative and stopped building new contributions.

Categorization of professors: The code system used in the content analysis was the following

- Presence (or absence) of discursive elements in favor of creativity promotion.

- Presence (or absence) of discursive exemplifications of actions that promote creativity.

- Presence (or absence) of discursive elements in favor of creativity obstruction.

- Presence (or absence) of discursive exemplifications of actions hindering of creativity.

In order to give more meticulousness to the data collection, 11 categories were ellaborated refeered to promotion or obstaculization of creativity (they are presented in Table 1).

We also discrimininated, for each one of them, the discursive valorization of the concrete actions exemplification. This last one is considered as more valuable as we understand they approach to facts more than what they do to opinions, and they result more liable when categorazing teachers as promoters or obstructive.

Starting from the analysis of the interviews with students and teachers under these patterns, teachers have been classified according to the following categories:

- Highly Creativity Promoter teacher (HCP): it is considered to those teachers which's speech is full in conceptions and in exemplifications with emphasis, their actions are according to a creative school, and not manifesting nor suggesting creativity obtstructive elements;

- Creativity Promoter teacher (CP): Teachers who repeatedly manifest opinions or conceptualizations belonging to a creative school and exemplify or suggest some specific action. They don't manifest nor suggest creativity obstructive elements.

- Possible Creativity Promoter teacher (PCP): The one who suggests few elements according to a creative school, and doesn't manifest nor suggest creativity obstructive elements.

- Neutral teacher (N): Their speech doesn't present elements either in favor or against promotion of creativity.

- Creativity Hindering Teacher (CH): The one who regardless to his speech, exemplifies creativity obstructive actions.

- Highly Creativity Hindering teacher $(\mathbf{H C H})$ : Teachers that have a speech that is clearly obstructive of creativity, with concepts and actions that support their perspective.

\footnotetext{
${ }^{1}$ In Uruguay, teacher training for middle education offers careers by specialties (Biologic Sciences, Physics, Chemistry, Maths, etc) granting a specific University degree for each area. The career has subjects that are part of the "commun nucleus" (these subjects are the same for every career specification), and "specific" ones that are proper of each orientation.

${ }^{2}$ The current regulations stablishes that range of marks goes from 1 to 12. Except the subjects with a workshop character, all the rest of them present a final exam, unless the overall average of the student in that subject is equal or higher than 9.
} 
Table 1. Elements that refeer to promotion or obstruction of Creativity considered in the analysis of interviews for data codification and professors categorization.

\begin{tabular}{|c|c|c|c|c|}
\hline Studied Qualities & $\begin{array}{l}\text { Discursive elements in } \\
\text { favor of creativity } \\
\text { promotion }\end{array}$ & $\begin{array}{l}\text { Exemplification of } \\
\text { creativity promoting } \\
\text { actions }\end{array}$ & $\begin{array}{l}\text { Discursive elements in } \\
\text { favor of creativity } \\
\text { obstruction }\end{array}$ & $\begin{array}{l}\text { Exemplification of obstructive } \\
\text { actions }\end{array}$ \\
\hline 1. Type of learning & $\begin{array}{c}\text { The teacher is in favor of } \\
\text { active learning, focused on } \\
\text { the student }\end{array}$ & $\begin{array}{l}\text { Promotes active learning, } \\
\text { centered on the student }\end{array}$ & $\begin{array}{c}\text { Values the passive role } \\
\text { of the student and } \\
\text { learning centered on } \\
\text { content }\end{array}$ & $\begin{array}{l}\text { Promotes the passive role of } \\
\text { the student and centered on } \\
\text { centent. (e.g. Te teacher gives } \\
\text { lectures, students take notes) }\end{array}$ \\
\hline $\begin{array}{l}\text { 2. Information } \\
\text { Management }\end{array}$ & $\begin{array}{c}\text { Disapproves accumulation } \\
\text { of information, manifesting } \\
\text { himself in favor of its } \\
\text { hierarchization }\end{array}$ & $\begin{array}{l}\text { Prioritizes hierarchization } \\
\text { of information and } \\
\text { discourages memorization } \\
\text { of information }\end{array}$ & $\begin{array}{c}\text { In favor of rote learning } \\
\text { and of the information } \\
\text { accumulation }\end{array}$ & $\begin{array}{l}\text { Stimulates rote learning and } \\
\text { information accumulation }\end{array}$ \\
\hline $\begin{array}{l}\text { 3. Decision-making by } \\
\text { students (autonomy) }\end{array}$ & $\begin{array}{c}\text { In favor of decision taking } \\
\text { by students }\end{array}$ & $\begin{array}{c}\text { Stimulates decision taking } \\
\text { by students and gives } \\
\text { opportunities for that to } \\
\text { happen }\end{array}$ & $\begin{array}{l}\text { Does not value decision } \\
\text { taking by students }\end{array}$ & $\begin{array}{l}\text { Limits the decision taking by } \\
\text { students }\end{array}$ \\
\hline 4. Self-learning & $\begin{array}{l}\text { Values metacognition and } \\
\text { self evaluation }\end{array}$ & $\begin{array}{l}\text { Stimulates metacognition } \\
\text { and self evaluation }\end{array}$ & $\begin{array}{l}\text { Does not manifest } \\
\text { against metacognition } \\
\text { and self evaluation by } \\
\text { students }\end{array}$ & $\begin{array}{c}\text { Does not stimulate } \\
\text { metacognition nor self } \\
\text { evaluation of the students }\end{array}$ \\
\hline $\begin{array}{l}\text { 5. Students' self } \\
\text { esteem }\end{array}$ & $\begin{array}{l}\text { Worries about self esteem } \\
\text { of the students }\end{array}$ & $\begin{array}{l}\text { Stimulates self esteem of } \\
\text { the students }\end{array}$ & $\begin{array}{c}\text { Does not manifest to be } \\
\text { worried about students' } \\
\text { self esteem }\end{array}$ & $\begin{array}{c}\text { Does not stimulate students' } \\
\text { self esteem }\end{array}$ \\
\hline $\begin{array}{l}\text { 6. Value of discussion, } \\
\text { problematization and } \\
\text { critical thinking }\end{array}$ & $\begin{array}{l}\text { Values discussion and } \\
\text { problematization, as well } \\
\text { as critical thinking }\end{array}$ & $\begin{array}{l}\text { Promotes discussion, } \\
\text { problematization and } \\
\text { critical thinking }\end{array}$ & $\begin{array}{l}\text { Does not value } \\
\text { discussion, } \\
\text { problematization nor } \\
\text { critical thinking }\end{array}$ & $\begin{array}{l}\text { Limits or penalizes discussion } \\
\text { and problematization. Does } \\
\text { not stimulate critical thinking. }\end{array}$ \\
\hline 7. Divergent thinking & $\begin{array}{l}\text { Values the divergent } \\
\text { thinking promotion }\end{array}$ & $\begin{array}{l}\text { Promotes divergent } \\
\text { thinking }\end{array}$ & $\begin{array}{l}\text { Does not value } \\
\text { promotion of divergent } \\
\text { thinking }\end{array}$ & $\begin{array}{c}\text { Stimulates convergent } \\
\text { thinking but not the divergent } \\
\text { one. }\end{array}$ \\
\hline 8. Team Work & Values team work & Stimulates team work & $\begin{array}{l}\text { Does not value team } \\
\text { work }\end{array}$ & Does not stimulate team work \\
\hline $\begin{array}{l}\text { 9. Professor's } \\
\text { Tolerance (Flexibility) }\end{array}$ & $\begin{array}{l}\text { Suggests tolerance towards } \\
\text { students’ proposals }\end{array}$ & $\begin{array}{l}\text { Accepts students' } \\
\text { suggestions and convert } \\
\text { them into actions }\end{array}$ & $\begin{array}{c}\text { Rigid against students' } \\
\text { proposals, lack of } \\
\text { flexibility, structured } \\
\text { professor. }\end{array}$ & $\begin{array}{l}\text { Intolerant. Does not allow } \\
\text { students to make suggestions }\end{array}$ \\
\hline $\begin{array}{l}\text { 10. Teacher's } \\
\text { self-concept in relation } \\
\text { to knowledge. }\end{array}$ & $\begin{array}{l}\text { Does not consider } \\
\text { himself/herself to be } \\
\text { omniscient }\end{array}$ & $\begin{array}{l}\text { Recognizes his/her own } \\
\text { limitations and is always } \\
\text { willing to learn from the } \\
\text { students }\end{array}$ & $\begin{array}{l}\text { The teacher considers } \\
\text { himself omniscient }\end{array}$ & $\begin{array}{l}\text { Does not recognize his/her } \\
\text { limitations nor the possibility } \\
\text { to learn from the students }\end{array}$ \\
\hline $\begin{array}{l}\text { 11. Innovation in } \\
\text { teaching }\end{array}$ & $\begin{array}{c}\text { In favor of innovation in } \\
\text { teaching }\end{array}$ & $\begin{array}{l}\text { Exemplifies innovative } \\
\text { actions in his/her classes }\end{array}$ & $\begin{array}{c}\text { Does not value } \\
\text { innovation in teaching }\end{array}$ & $\begin{array}{c}\text { Gives stereotyped classes } \\
\text { without variations }\end{array}$ \\
\hline
\end{tabular}

As a quality control and following the guidelines of Andréu Abela (2002), once the codes and categories that made the sistematization of data collection possible were adjusted, all the interviews were reanalyzed in order to make sure all of them were measured by the same criteria.

\section{Results}

Showing up next as an example there are some interview excerpts with the objective of illustrating the interpretation criteria that enabled us to categorize the proffesors.

Examples of teachers'speeches excerpts considered in favor of "Creativity promotion":

In relation to looked and promoted or valued qualities in students:

- "...the level of reflection, the capacity of changing subjects and being able to link them; learning to learn. Beyond memoristic,.. When I compare, what am I doing?; when I define, what am I doing?; what is to hierarchize?, what does "order" means?..." (We interpret the teacher encourages deep learning and not 
superficial, as well as metacognition, according to an active learning. It refeers to points 1 and 4 of the table).

- "The question he/she asks in class, the comments she/he is able to make about the given topic,... it can be a doubt or a thought, or the way he/she reflects, even when being wrong." (Related to points 1, 6 and 7 of the table).

In relation to concrete actions by teachers:

- "I give my students exercises starting with the easiest ones and then finishing with the hardest ones, because of their self esteem..." (The professor concerns repeatedly about the students' self esteem and looks after ways to encourage it. Point 5 of the table, column 2).

- "They resolve exercises in groups,... Exercises don't have a unique solution, there are many ways to solve them..." (Promotes work in groups and divergent thinking. Point 7 and 8 of the table).

- "They must choose which area to investigate, how to manage schedules,... how to deliver the work, I gave free will as to the evaluation format refeers, they can make a poster, a written inform, something that could be published in a congress or a in a magazine... they must decide,..." (Promotes autonomy, point 3 of the table).

- "I think the example is also important, if you as teacher make a mistake and you recognize it, saying for example "ah...I was wrong"...or if you read things with your students. Demystifies the idea of the omniscient teacher..." (Point 10 of the table).

Examples of excerpts of teachers' speeches that have been considered as in favor of "Obstruction of creativity":

In relation to looked and promoted or valued qualities in students:

- "...they start preparing the topics, asking you to explain them, ...The student that brings you questions not only because you explained something in a way he didn't understood, but also that tells you that some book says this or that...well...what's the truth?... There are two types of students..." (Suggests a passive role of the student in class by giving the idea that the teacher "gives the class" and by saying that the students "prepair the topics" intimating learning focused on the content, possibly memoristic. Saying there is "one trhuth" and "two types of students" goes hand in hand with being a rigid and an inflexible teacher. Refeers to points 1, 2 and 9 of the table).

- "accurate participations, that reads, that provides new information." (Leaves no room for error, hierarchizes learning focused on content. Refeers to points 2, 6 and 7 of the table).

In relation to specific actions by teachers:

- "I have a very strong personality, so I never had students that disorganized or disturbed my class..." (Point 9 of the table)

- “...I evaluate curricular content...” (Point 9 of the table). "You ask them: don't you take notes? And they respond: no, I will read it from the book...”. (The teacher cataloges those students as arrogant. Omniscient teacher. Point 10 of the table).

- "The confidence that gives you the experience of all these years... in which you have been inquiring, studying, looking after detalis, that when you first prepair a topic... I could be conductist but the disciplinary dimension seems fundamental to me..." (Point 2 of the table).

Examples of exceprts of students' speeches (referring to teachers) that have been considered as in favor of "creativity promotion":

In relation to teachers' qualities valued or promoted:

- "With that teacher I wasn't afraid of making mistakes..." (Infers teacher who doesn't punish error and promotes the student's self esteem. Refeers to point 5 of the table).

- "...Autonomy in decisions taking, in didactic... Working in groups is encouraged... Being able to problematize, too,... the flexibility,...” (Points 3, 6, 8 and 9 of the table).

Examples of excerts of students' speeches (referring to teachers) that have been consider in favor of "creativity obstruction":

- “... Many times they make emphasis on details that maybe are not so important...” (Refers to point 2).

- "Each year I have problems... in the oral exam I said I wasn't agree... Not understanding the epistemological complexity happens to teachers of teachers, because most of them want mirrors...” (Refers to points 6 and 9 of the table).

- “...They wanted to correct me things that were actually correct. Autonomy was not very allowed...” (Refers 
to points 3 of the table).

\section{Discussion}

In the analyzed sample there is a predominance of promoter teachers over hindering ones, both in student's and in teachers' interviews' results.

In relation to categorization of hindering and promoter teachers, we propose that:

Professors categorized as "Hihly Creativity Promoters" are descripted as close in the relationship with the students, not with an omniscient attitude and teachers with whom the students are not afraid to fail. Students always refer to them with affection. Teachers categorized as "Highly Creativity Hindering" are descripted as structured, omniscient and distant in relationships.

In two cases, we obtained apparently contradictory data. A case referred to a teacher categorized as a promoter of creativity and another to a highly qualified teacher as hindering creativity. In both cases, it appeared that students were talking about someone else. In the second case, the student described a particular ocasion in which that professor gave him the liberty to prepair a class, asking the student "to surpsise him".

While in the first case the student infers a cold and distant relationship by the professor, in the second one the pupil manifests a big admiration and idealization of the professor. Both students seem to be talking about a different person.

We interpreted this data considering that what the students said came from their subjectivity, which can be altered and influenced by emotional ties and relationship with the professors. Results suggest that:

- Creativity promoter actions, may not have positive results, if the relationship between the teacher and the students is distant; and that

- In cases in which the relationship between the teacher and the students is close, even hindering teachers could have specific creativity promoter actions.

These findings hierarchize the emotional bond between the teacher and the student, as a key element in a creative class.

\section{Conclusion}

It is possible, based on professors's interviews, to differentiate them between creativity promoters or hindering.

When one of these two characteristics turns out to be prominent, the one is confirmed by the students' reports.

Students relate "Highly Creativity Promoter" teachers with those who are close to them, warm, who doesn't have an omniscient attitude and that recognize mistakes; and "Highly Creativity Hindering" teachers with those who are structured, distant and unflexible.

As an emergent result to highlight, we pose that creativity promoter actions are only visible by students which's bond between the teacher and them is warm and close. Likewise, an affectionate treatment from the student towards the professor may unchain creativity promoter actions even in hindering teachers.

We propose that affection constitutes an essential dimension in the professor-student interaction in a creative class, being able to play a relevant role, feedback in that interaction. In this way, this study continues and deepens the Csikszentmihelyi's systematic model. While this author emphasizes the interaction between the creative person and the ambit of experts that recognize and valids his production, this work hierarchizes the interactions in the teacher-student binomial in a creative class and the feedback, positionating affection in a central position in interaction. Analogously to the thinking that a creative product doesn't emerge from the mind of an isolated person, it seems appropiate to affirm that the promoter or hindering profile of a professor, also depends on the interactions with his environment.

\section{References}

Adorjan, A., \& Friss, I. (2014). Design and Experimentation of Activities for CS1: A Competences Oriented Approach (Unpacking the Informed Design Teaching and Learning Matrix). CLEI Electronic Journal, 17, 1-14.

Amabile, T. (1998). How to Kill Creativity. Harvard Business Review, 77-87.

Amabile, T. M. (1983). The Social Psychology of Creativity: A Componential Conceptualization. Journal of Personality and Social Psychology, 45, 357-376. http://dx.doi.org/10.1037/0022-3514.45.2.357

Andréu Abela, J. (2002). Technical Content Analysis: An Updated Review. Publication Andalusian Studies Centre. 
http://public.centrodeestudiosandaluces.es/pdfs/S200103.pdf

Babicka, A., Dudek, P., Makiewicz, M., \& Perzycka, E. (2010). Professor Creative Competition. Revista Electrónica Interuniversitaria de Formación del Profesorado, 13, 51-61.

Bilhalva, K. Y., \& Blanché, S. (2015). El laboratorio de lengua: Una experiencia creativa con TIC en formación docente. Virtualidad, Educación y Ciencia, 10, 91-104.

Craft, A., Cremin, T., Hay, P., \& Clack, J. (2014). Creative Primary Schools: Developing and Maintaining Pedagogy for Creativity. Ethnography and Education, 9, 16-34. http://dx.doi.org/10.1080/17457823.2013.828474

Csikszentmihalyi, M. (1999) Implications of a Systems Perspective for the Study of Creativity. In R. J. Sternberg (Ed.), Handbook of Creativity. Cambridge: Cambridge University Press.

de la Torre, S. (2009). The University We Want. Creative Strategies in the University Classroom. Revista Digital Universitaria, 10. http://www.revista.unam.mx/vol.10/num12/art89/int89.htm

Elisondo, Romina, Donolo, \& Rinaudo, D. M. C. (2009). Occasions for Creativity in Higher Education Contexts. Revista de Docencia Universitaria. www.um.es/ead/Red U/4/elisondo.pdf

Feist, G. (1998). A Meta-Analysis of Personality in Scientific and Artistic Creativity. Personality and Social Psychology Review, 2, 290-309. http://dx.doi.org/10.1207/s15327957pspr0204 5

Ferrari, A., Cachia, R., \& Punie, Y. (2009). Innovation and Creativity in Education and Training in the EU Member States: Fostering Creative Learning and Supporting Innovative Teaching. JRC Technical Notes. Publication of the European Community. http://ftp.jrc.es/EURdoc/JRC52374_TN.pdf

Guilford, J. P. (1975). Creativity: A Quarter Century of Progress. In I. A. Taylor, \& J. W. Getzels, (Eds.), Perspectives in Creativity. Chicago: Aldine Publishing Co.

Henriksen, D. (2014). Full STEAM Ahead: Creativity in Excellent STEM Teaching Practices. The STEAM Journal, 1. http://scholarship.claremont.edu/steam/vol1/iss2/15 http://dx.doi.org/10.5642/steam.20140102.15

Huidobro Salas, T. (2004). A Definition of Creativity through the Study of 24 Authors Selected. Doctoral Thesis. Madrid: Universidad Complutense de Madrid.

Jiménez Fernández, C. (2000). Diagnosis and Education of the Ablest. Madrid: UNED.

Lewisa, M., \& Elaver, R. (2014). Managing and Fostering Creativity: An Integrated Approach. The International Journal of Management Education, 12, 235-247. http://dx.doi.org/10.1016/j.ijme.2014.05.009

Marquis, E., \& Henderson, A. (2015). Teaching Creativity across Disciplines at Ontario Universities. Canadian Journal of Higher Education, 45, 148-166.

Newton, L. D., \& Newton, P. D. (2014). Creativity in 21 $21^{\text {st }}$-Century Education. Prospects, 44, 575-589. http://link.springer.com/article/10.1007/s11125-014-9322-1\#page-1

Pascale, P. (2005). Where Is the Creativity? An Approach to Model Systems Mihaly Csikszentmihalyi. Arte, Familia y Sociedad, 17, 61-84.

Pérez Alonso-Geta, P. M. (2009). Creativity and Innovation: A Acquirable Skill. Teoría de la Educación, 21, 179-198.

Rebollo, C., \& Soubirón, E. (2014). The Generation of Open Educational Resources (OER) in Learning Chemistry Teacher Training in URUGUAY. Congreso Iberoamericano de Ciencia, Tecnología, Innovación y Educación. http://www.oei.es/congreso2014/memoriactei/261.pdf

Romo Santos, M. (1987). Thirty-Five Years of Divergent Thinking: Theory of Creativity Guilford. Revista Estudios de Psicología, Universidad Autónoma de Madrid, 27-28, 175-192.

Soriano de Alencar, E. (2007). Creativity in the educational Context. Three Decades of Research. Psicologia: Teoria e Pesquisa, 23, 45-49.

Tan, C. L. (2014). The Curricular and Pedagogic Creativity of Summerhill School, and Related Reflection on the Teaching in Singapore. Journal of Education and Human Development, 3, 541-557.

Tenti Fanfani, E. (2013). Some Dimensions of the Professionalization of Teachers. Representations and Policy Issues Agenda. BID Publication.

http://publications.iadb.org/bitstream/handle/11319/2398/Algunas\%20dimensiones\%20de\%20la\%20profesionalizaci\%C3 \%B3n\%20de\%20los\%20docentes.\%20Representaciones\%20y\%20temas\%20de\%20la\%20agenda\%20pol\%C3\%ADtica..p df?sequence $=1$ 


\section{Submit or recommend next manuscript to SCIRP and we will provide best service for you:}

Accepting pre-submission inquiries through Email, Facebook, Linkedin, Twitter, etc A wide selection of journals (inclusive of 9 subjects, more than 200 journals)

Providing a 24-hour high-quality service

User-friendly online submission system

Fair and swift peer-review system

Efficient typesetting and proofreading procedure

Display of the result of downloads and visits, as well as the number of cited articles

Maximum dissemination of your research work

Submit your manuscript at: http://papersubmission.scirp.org/ 